\title{
Structural sawn timber: resource enhancement
}

\section{Увеличение ресурсов конструкционных пиломатериалов для строительных конструкций}

\author{
V.E. Byzov, \\ St. Petersburg State University of Architecture and \\ Civil Engineering, St. Petersburg, Russia \\ V.I. Melekhov, \\ Northern (Arctic) Federal University named after \\ M.V. Lomonosov, Arkhangelsk, Russia
}

\author{
Канд. техн. наук, доцент В.Е. Бызов, \\ Санкт-Петербургский государственный \\ архитектурно-строительный \\ университет, Санкт-Петербург, Россия \\ д-р техн. наук, професссор В.И. Мелехов, \\ Северный (Арктический) феедеральный \\ университет им. М.В. Ломоносова, \\ е. Архангельск, Россия
}

Key words: wood; strength and testing of materials; timber structures; quality control

\author{
Ключевые слова: древесина; прочностные \\ характеристики; сердцевинные брусья; \\ совокупный объём сучков; прочностные \\ группы; конструкционные пиломатериалы
}


Currently, in the Russian Federation, the strength properties of deflected sawn timber determine its attribution to grades 1,2 and 3 according to Russian State Standard GOST 8486 "Coniferous sawn timber. Specifications". The requirements for timber of the relevant grade are determined by the presence and size of wood defects, such as knots, cracks, wood structure defects and others. The strength properties of grade 1 according to Russian State Standard GOST 8486 approximately corresponds to C30 strength class according to EN 338, whereas grades 2 and 3 correspond to C24 and C16 strength classes, respectively.

However, due to high variability of strength properties of wood, even within the same species and the same site, the strength of sawn timber and modulus of elasticity may vary considerably within the same grade of timber. At the same time, in practice, the standard values of sawn timber of several grades show little difference. Numerous studies conducted by Russian and foreign scientists [1-4] confirm that the parameters used to determine the strength of timber poorly characterize its strength properties.

Modern wood processing industry now faces more and more acute problem related to deterioration of the size and quality of round timber used for manufacturing sawn structural timber. Reduced cross section of blanks results in irrationally high percentage of wood sawing residue due to inadequate assessment of the strength properties under the existing national standards. Some planks with insufficient strength properties are used to manufacture load-bearing structures, while those, characterized by sufficient strength, are prohibited to use by the existing codes and standards. This is due to the fact that the size of defects used to classify timber and attribute it to a certain grade does not fully characterize its strength properties. The grade of sawn timber is largely determined by the sizes of knots it has.

It is obvious that if strength is evaluated according to the size of knots on the faces and edges of a plank, measured according to traditional methods, the requirements of production are no longer met. Thus, since the existing standards for determining the strength of sawn timber fail to meet the modern requirements for energy conservation and rational use of resources, a new standard should be developed for identifying the strength properties of timber. For this purpose, we have developed a method that increases accuracy in assessment of strength properties of sawn timber.

Adaptation of sawing technology to degraded quality of the source material became a key element in the new standard of sawn timber strength. On the one hand, there is need to increase the strength of those grades of timber which in the current system of standards are classified as nonconforming. Such increase could be achieved by changing the sawing technology. On the other hand, there is a high demand for the standards that would reduce the amount of waste and scrap in the course of production. Similar issues were raised in Gradewood project [5], though one of its main objectives was to analyze the old and new destructive tests of the quality of structural wood products. This article is an attempt to prove the existence of correlation between strength properties and appearance of sawn timber, and thus makeit possible to develop new standards for non-destructive tests for wood products grading.

\section{Sawing into heartwood beams for increased strength of sawn timber}

As it is known, the main type of the deflected mode to which the elements of load-bearing structures are exposed, is lateral bending. In the majority of cases, the cross-section of sawn timber has a wide side, called the "face" and a narrow one, called the "edge". The deflected mode strength of the loaded edge has been considered traditionally as the measure of strength. In order to increase the deflection strength of the elements within a structure, they are arranged in a way that allows them to be exposed to load on the edge [6].

According to the results of research [7], the structure of wood in the trunk of a growing tree, owing to ring-type cross-section of its annual layers, enhances its strength against the bending moment of wind load. In addition, the strength is increased due to the nature of the layered structure of wood, i.e. early wood and latewood alter within the annual layer and thus a capability of additional deflection is created. Additional deflection is possible due to shifts in weak layers of early wood when the trunk is subjected to lateral force.

Increased deflection reduces the bending moment, in particular, under wind loads [8]. These features of the natural structure of the tree trunk should be applied in the manufacture of elements in supporting and load-bearing structures. Thus, it is very important that the maximum number of uncut annual layers is preserved within the timber. For more accurate quantitative and qualitative assessment of relationship between wood structure and strength properties thereof, it seems reasonable to formulate 
the objective of the research, which is to examine the wood structure at macro level as aclosed system of shells.

Round wood assortment, which is used to produce structural sawn timber, may be schematically represented as a system of thin-walled shells coaxially threaded one over the other to simulate the pattern of annual rings of wood [9]. The core is located in the central part of the assortment cross section. Structural sawn timber of large cross sections made from round assortment retains the ring structure of annual layers of wood to the fullest extent (Figure 1).

Sawn timber of large cross section obtained from small diameter round timber consists of a core and retains the maximum macrostructure of a growing tree trunk, which is a natural structural material with increased strength properties. These are so-called heartwood beams. Thus, the use of square beams made of heartwood allows for expansion of sawn timber resources for the production of loadbearing structures.

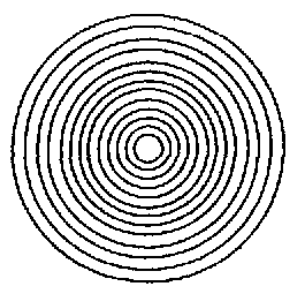

b

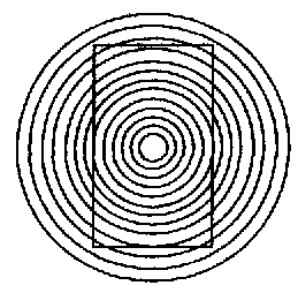

c

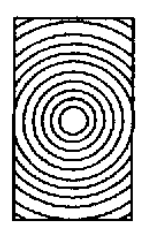

Figure 1. The structure of heartwood sawn timber:

a - roundwood assortment; b - cutting plan for the roundwood assortment; c- cross section of a heartwood timber plank

\section{Methods}

It should be noted that the quantitative evaluation of mechanical characteristics of heartwood timber is still insufficiently studied and not defined. Direct determination of strength parameters is associated with destruction of sawn timber and that does not meet the requirements for resource conservation. In order to reduce the percentage of waste and scrap in production of timber, it is advisable to carry out non-destructive strength testing. To improve the reliability of strength test for timber produced from small saw logs given their macrostructure, it is necessary to define evidence-based criteria for finding out the most relevant parameters and carry out their standardization for assessment of the strength of the sawn timber.

The basis for development of this method is represented by the studies of the relationship between the strength of sawn timber and the parameters determined without destruction of sawn timber, i.e. the so-called indirect parameters of strength. The indirect parameters can only be thosepresent in all samples of sawn timber that undergo strength assessment. These parameters are biological properties of wood, i.e. defects and above all, knots [10-14].

In accordance with that, the task was to change the approach to the assessment of timber strength based on a method of differentiation of defect standards. The defect standards should take into account the deflected mode of timber in load-bearing engineering structures. Increase of reliability of visual assessment of strength properties of timber implies substantiation of efficiency of the new and most significant indirect grading parameter of strength.

As a result of tests aimed at assessment of strength properties of timber, the aggregate knot volume at destruction section was adopted as the key parameter, which is defined as the ratio of total volume of knots located within the section with the length equal to the width of the plank to the volume of this section [15] (Figure 2). This parameter reflects, in the best way, the reduction in strength due to the presence of knots in heartwood. Foreign companies are familiar with the use of standards for visual grading of sawn timber according to the parameters of knots. In particular, the UK applies BS 4978:2007 + A1:2011 "Visual strength grading of softwood. Specification". This standard specifies the requirements for two grades of visual grading of softwood timber, namely general structural grade (GS) and special structural grade (SS). Grading of sawn timber is performed in accordance with the KAR and MKAR standard parameters of knots. The KAR (knot area ratio) is the ratio of knot projections area of a sawn timber section to the area of their cross section. The MKAR (margin knot area ratio) is the ratio of the area of knot projections, present in the margin zone, to the margin zone area of sawn timber. In order 
to improve the rules for softwood grading, the European standard EN 1912-2012 "Structural timber. Strength classes. Assignment of visual grades and species" came into force in 2012.

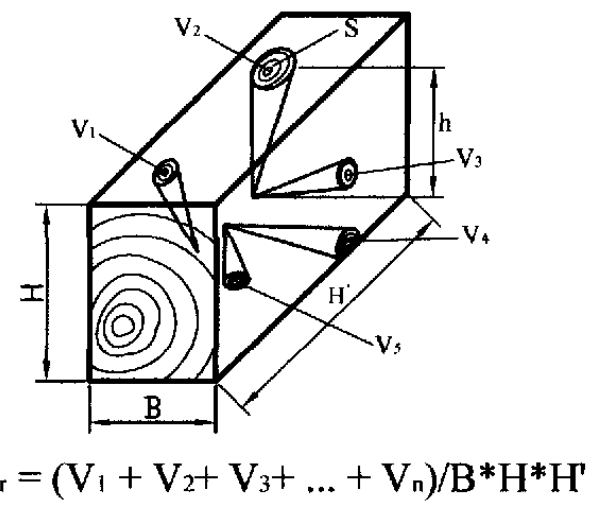

Figure 2. The aggregate knot volume at destruction section:

$\mathrm{V}_{\text {agr }}$ - aggregate knot volume at destruction section;

$V 1, V 2, \ldots V n-k n o t$ volumes at destruction section; $\mathbf{S}-\mathbf{k n o t}$ section area; $\mathbf{h}$ - knot height; B - sawn timber width; $\mathrm{H}$ - sawn timber height; $\mathrm{H}^{\prime}$ - destruction section length

\section{Results and Discussion}

We have carried out comprehensive research in order to develop quality requirements for heartwood timber and provide the desired strength properties for different types of deflected mode. We have obtained quantitative assessments of the strength properties of softwood timber through testing the samples of timber planks for bending load on the edge and compression along the grain. The test samples of timber were obtained from logs harvested in the forests of the Northern European part of Russia.

According to the results of the sawn timber certification, the values of the relative aggregate knot volume in destruction sections were identified, and tests were conducted to determine the strength properties of sawn timber. The cross-sectional dimensions of the samples tested for bending load on the edge and compression along the grain were $100 \times 150 \mathrm{~mm}$. These dimensions were chosen in accordance with Russian State Standard GOST 24454, which determines the sizes of construction materials.

The depth of the samples used in deflection tests was $150 \mathrm{~mm}$. Their length was 20 times the depth, i.e. $3000 \mathrm{~mm}$. We used 4-point bending, as in EN 408. The beam span was 18 times the depth. The span between the points of loading was 6 times the depth, i.e. $900 \mathrm{~mm}$. The sample tested was symmetrically loaded at two points over the span (Figure 3). The tests were performed on a hydraulic testing machine R-20 with the use of a special device ensuring the necessary loading regime.

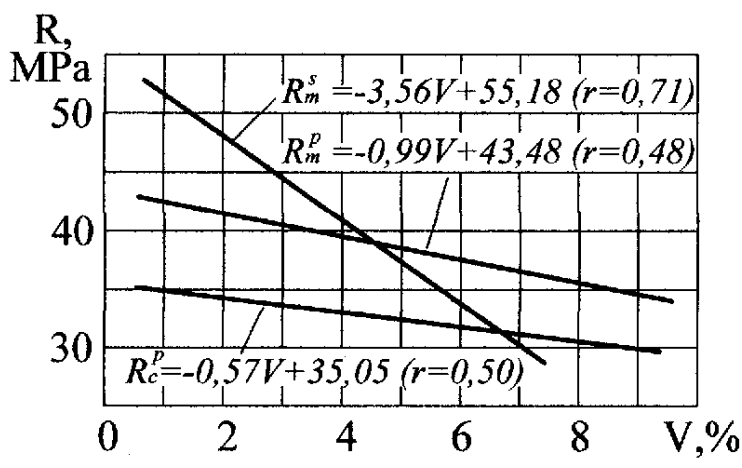

Figure 3. Bending test

The length of the samples used in compression tests was $400 \mathrm{~mm}$, not 6 times the smaller crosssectional dimension, as in EN 408. The specimen was loaded along the axis by using spherically sealed loading heads, ensuring application of the compressive load without inducing bending (Figure 4). The tests were performed using hydraulic press with the accuracy of $\pm 2 \%$ of the applied load.

Byzov V.E., Melekhov V.I. Structural sawn timber: resource enhancement. Magazine of Civil Engineering. 2016. No. 5. Pp. 67-76. doi: 10.5862/MCE.65.5 


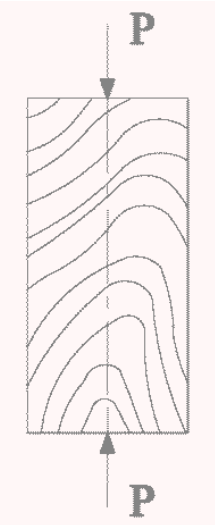

\section{Figure 4. Compression test}

We obtained data on a totality of distributions of ultimate strength parameters for beams for the cases involving bending through loading the edge and compression along the grain, as well as distribution of values for the relative aggregate knot volume at destruction sections. The conformance test aimed to check the empirical distributions against the general distribution law confirmed that there is possibility for approximation of experimental distributions in relation to this theoretical law. Table 1 shows the results of the statistical analysis of strength parameters and aggregate knot volume parameters.

Table 1. Statistical parameters of distribution

\begin{tabular}{|c|c|c|c|c|c|c|c|}
\hline Type of stress- & Species & Parameters ${ }^{1)}$ & $\begin{array}{c}\text { Number of } \\
\text { strain state }\end{array}$ & & & \multicolumn{4}{|c|}{ Statistics ${ }^{2)}$ of empirical distribution } \\
\cline { 5 - 8 } & & tested & $\bar{X}$ & $\sigma_{x}$ & $X_{0.95}$ & $\omega^{2}$ \\
\hline $\begin{array}{c}\text { Bending through } \\
\text { loading the edge }\end{array}$ & spruce & $R, \mathrm{MPa}$ & 54 & 45.8 & 8.8 & 31.3 & 0.27 \\
\hline $\begin{array}{c}\text { Bending through } \\
\text { loading the edge }\end{array}$ & pine & $R, \mathrm{MPa}$ & 52 & 35.9 & 9.5 & 20.2 & 0.36 \\
\hline $\begin{array}{c}\text { Compression } \\
\text { along the grain }\end{array}$ & pine & $R, \mathrm{MPa}$ & 42 & 31.7 & 4.9 & 23.6 & 0.91 \\
\hline $\begin{array}{c}\text { Bending through } \\
\text { loading the edge }\end{array}$ & spruce & $V, \%$ & 54 & 2.7 & 1.7 & - & 0.81 \\
\hline $\begin{array}{c}\text { Bending through } \\
\text { loading the edge }\end{array}$ & pine & $V, \%$ & 52 & 7.6 & 4.8 & - & 1.04 \\
\hline $\begin{array}{c}\text { Compression } \\
\text { along the grain }\end{array}$ & pine & $V, \%$ & 42 & 7.1 & 4.7 & - & 0.49 \\
\hline
\end{tabular}

Note:

${ }^{1)}$ Parameters:

$R$ - ultimate stress;

$V$ - aggregate knot volume in the destruction section.

${ }^{2)}$ Statistics:

$\bar{X}$ - arithmetical average (mean);

$\sigma_{x}$ - root-mean-square deviation;

$X_{0.95}$ - permissible limit (lower tolerable) with probability of 0.95 ;

$\omega^{2}$ - test for concordance of experimental distribution with theoretical distribution law (if $\omega^{2} \leq 1.94$, then the hypothesis of concordance is adopted with significance value of 0.1 ).

$b$ - regression equation ratio;

$a$ - absolute term of regression equation;

$r$ - correlation coefficient;

$S_{y x}$ - standard error of estimation.

The table clearly shows the point estimations of distribution of ultimate strength values and relative aggregate knot volume in the destruction sections, which were determined by a test involving bending

Бызов В.Е., Мелехов В.И. Увеличение ресурсов конструкционных пиломатериалов для строительных конструкций // Инженерно-строительный журнал. 2016. № 5(65). С. 67-76. 
through loading the edges of test samples made of spruce and pine, as well as compression along the grain of pinewood samples.

In order to carry out non-destructive testing of timber strength parameters, it is necessary to establish standards for an indirect strength parameter, which allows predicting the strength of the material without its destruction. In order to find the standards for aggregate knot volume, which correspond to the given strength properties of heartwood, regression analysis of the relationship of the ultimate strength parameter to the aggregate knot volume parameter was conducted in accordance with the existing methods [16].

The parameters of regression equations of coupling ultimate strength with the parameters of relative aggregate knot volume in the destruction section in deflected modes of bending through loading the edge and of compression along the grain are shown in Table 2.

Table 2. The parameters of regression equations

\begin{tabular}{|c|c|c|c|c|c|}
\hline \multirow{2}{*}{ Type of stress-strain state } & \multirow{2}{*}{ Species } & \multicolumn{4}{|c|}{ Regression parameters } \\
\cline { 3 - 6 } & $b$ & $a$ & $r$ & $S_{y x}$ \\
\hline $\begin{array}{c}\text { Bending through loading the } \\
\text { edge }\end{array}$ & spruce & -3.565 & 55.182 & 0.707 & 5.843 \\
\hline $\begin{array}{c}\text { Bending through loading the } \\
\text { edge }\end{array}$ & pine & -0.988 & 43.480 & 0.485 & 7.889 \\
\hline Compression along the grain & pine & -0.574 & 35.051 & 0.496 & 4.468 \\
\hline
\end{tabular}

The analysis of regression models of coupling the ultimate strength with the parameters of aggregate knot volume in the destruction sections allowed us to establish quantitative relationship, which became the basis for calculating the standards for the aggregate volume of knots, which maintain the given level of strength in deflected modes of bending through loading the edge and compression along the grain. On the basis of these standards, the regulations were developed to test the strength of timber in building structures, and a system of characteristic strength of timber was also adopted for production of components for load-bearing structures exposed to different types of deflected mode. We managed to calculate the characteristic values of the aggregate volume of knots, which provide for the strength of timber with sufficient reliability.

The regression models of coupling strength properties were established for spruce and pine timber under bending through loading the edge and compression along the grain of pinewood with aggregate knot volume parameter (Figure 5).
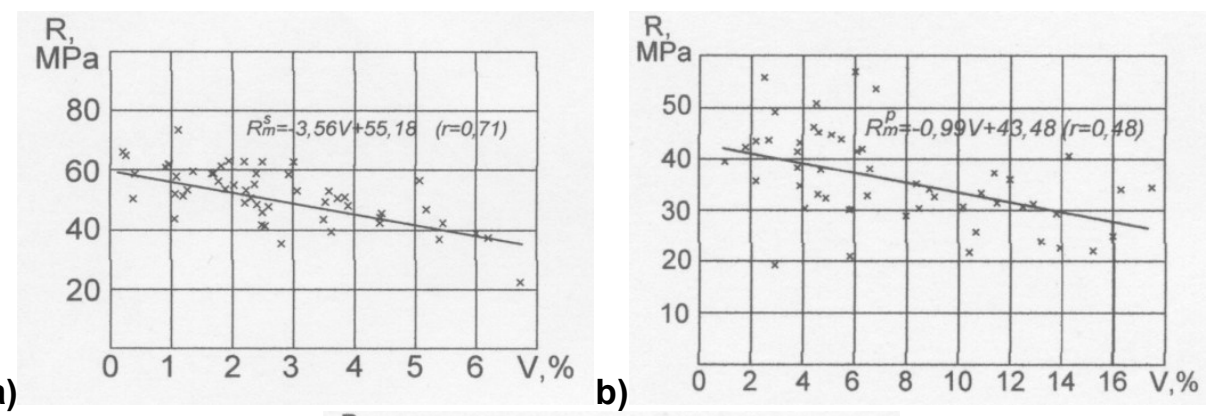

a)

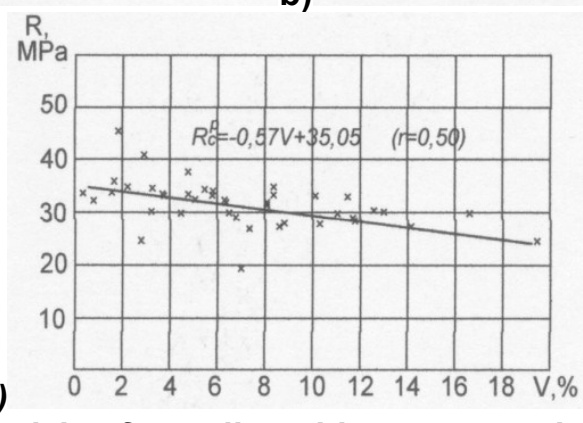

Figure 5. Regression models of coupling ultimate strength properties of samples with aggregate knot volume parameters:

a - bending through loading the edge (spruce); $b$ - bending through loading the edge (pine); $c$ - compression along the grain (pine)

Byzov V.E., Melekhov V.I. Structural sawn timber: resource enhancement. Magazine of Civil Engineering. 2016. No. 5. Pp. 67-76. doi: 10.5862/MCE.65.5 


\section{New standard for determination of strength properties} met:

When developing the guidelines for testing the strength parameter, the following conditions were

1. parameters of strength of beam grades;

2. practical solutions for strength testing;

3. beams output for various classes of strength.

The first condition implies that the strength parameters of timber corresponding to different types of deflected mode and strength grades must be linked to each other [17-19]. In addition, they must meet the actual needs for the production of components for load-bearing structures. The second condition implies cost efficiency and the need for adequate reliability of timber strength assessment. The third condition suggests that the need for production of timber of various grades of strength in terms of quantity should correspond to the production potential. There are various gradations of sawn timber strength [20, 21].

We adopted the following standards of grading the strength of sawn timber exposed to bending through edge loading and compression along the grain, i.e. 30, 24 and $15 \mathrm{MPa}$. These strength grades were identified, respectively, as $1 \mathrm{~K}, 2 \mathrm{~K}$ and $3 \mathrm{~K}$. The test limits for ultimate strength for grades of sawn timber, as well as the limits of parameters of aggregate knot volume for strength grades that ensure the above-mentioned ultimate strength, were identified. Test limits for separation of sawn timber by grades were set using the method proposed by V.V. Ogurtsov, which provides for dependencies for separating the sawn timber by strength grades with the necessary level of probability [22]. This method is used, because it allows determining the standards for other parameters of mechanical properties, e.g. compression of timber along the grain with the necessary level of probability upon finding the standard for the most important parameter of mechanical properties, such as the ultimate strength under bending on the edge.

In order to test the requirements elaborated for forecasting the strength properties of timber according to the aggregate knot volume parameters, we carried out tests involving a frame with parallel belts and a triangular lattice of beams graded by the relevant strength grades of $1 \mathrm{~K}, 2 \mathrm{~K}$ and $3 \mathrm{~K}$. The span of the frame was $18 \mathrm{~m}$, the height $-2.25 \mathrm{~m}$. The design load $q=17.2 \mathrm{kN}$ with the step of $6 \mathrm{~m}$. The tests were based on the worst possible loading scenario. In calculation of the frame strength, which was made based on the traditional technology, we established that the frame can sustain the total load of $310 \mathrm{kN}$. Destruction of the frame made of heartwood graded by strength grades occurred under the total load of $640 \mathrm{kN}$. The safety factor of the frame equaled 2.0.

\section{Classification of knots for visual evaluation of strength properties at production site}

Since at present there is lack of automated equipment allowing evaluating the aggregate size of knots, calculations were made based on the dependence of the sizes of knots on the faces and edges of heartwood timber from the aggregate volume of knots. All knots are divided into three categories, including edge knots, margin knots and axial knots (the used terminology as proposed by the author) (Figure 6). The edge knots appear on the edge of beams, whereas the margin knots appear on the face of a beam at a distance not exceeding two thirds of the diameter of the knot from the beam arise. The remaining knots on the face of a beam are axial knots. The size of the edge knot is defined as the distance between the tangents of the knot boundary, which are drawn in parallel to the beam arise. The size of a margin knot is determined by its smaller diameter. The size of a arise knot is determined by the smallest diameter or in the same way as the size of an edge knot is defined. The size of an axial knot is defined as arithmetical average (mean) between its largest and smallest diameters on the face of the beam. The allowable sizes are defined for edge, margin and axial knots and for knots present on the radial axis of the plank, provided that the proposed standard parameter of the relative aggregate size of knots per each strength grade is followed. The values of visually determined allowable sizes of knots are provided in Table 3. 


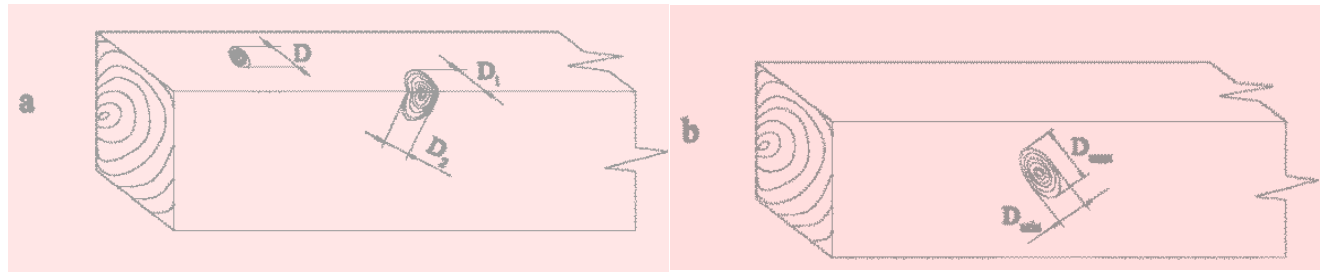

Figure 6. Classification and measurement of knots in the timber:

$a$ - including edge knots and margin knots; $b$ - axial knots;

D, D1, D2 - the size of knots on the face side and edges of the boards;

Dmax, Dmin - the maximum and minimum diameters of knots

Table 3. Visually allowable knot sizes for strength grades

\begin{tabular}{|c|c|c|c|c|}
\hline \multirow{2}{*}{$\begin{array}{c}\text { Name of } \\
\text { species }\end{array}$} & \multirow{2}{*}{ Strength grade } & \multicolumn{3}{|c|}{ Knot sizes in ratio to side width } \\
\cline { 2 - 5 } & & edge & margin & axial \\
\hline Spruce & $1 \mathrm{~K}$ & $1 / 3$ & $1 / 5$ & $1 / 5$ \\
\hline \multirow{2}{*}{ Pine } & $1 \mathrm{~K}$ & $1 / 3$ & $1 / 6$ & $1 / 6$ \\
\cline { 2 - 5 } & $2 \mathrm{~K}$ & $1 / 2$ & $1 / 3$ & $1 / 3$ \\
\hline
\end{tabular}

\section{Comparison with the current standard}

The comparative analysis of timber yield as per grades according to Russian State Standard GOST 8486 and upon grading by aggregate knot volume parameter (see Table 4) has shown that the yield of timber from heartwood graded in accordance with the developed standards and characterized by similar strength parameters, is greater.

The comparative analysis of timber yield as per grades under Russian State Standard GOST 8486 and strength grades has shown that the strength of all the types of spruce timber graded in accordance with the developed standards with the probability value of 0.95 makes up no less than $30 \mathrm{MPa}$ under bending through edge loading. At the same time, only $37 \%$ of spruce timber volume meets the requirements of grade 1 as per Russian State Standart GOST 8486. The characteristic strength of timber planks for grade 1 equals $26 \mathrm{MPa}$.

Table 4. Comparative analysis of timber yield

\begin{tabular}{|c|c|c|c|c|}
\hline Grading method & Wood species & Grade & $\begin{array}{c}\text { Strength value, } \\
\text { MPa }\end{array}$ & Yield, \% \\
\hline GOST & spruce & 1 & 26 & 37 \\
\hline & & 2 & 24 & 26 \\
\hline $\begin{array}{c}\text { Aggregate knot } \\
\text { volume }\end{array}$ & spruce & 3 & 16 & 4 \\
\hline GOST & pine & 1 "natural pruning" & 30 & 100 \\
\hline & & 2 & 24 & 38 \\
\hline $\begin{array}{c}\text { Aggregate knot } \\
\text { volume }\end{array}$ & pine & 3 & 16 & 22 \\
\hline & & $2 K$ & 24 & 83 \\
\hline
\end{tabular}

$83 \%$ of pinewood timber corresponds to $2 \mathrm{~K}$ strength grade with characteristic strength under bending through loading on the edge with $24 \mathrm{MPa} .40 \%$ of pinewood timber meets the requirements of grade 2 as per GOST 8486. Thus, in comparison with Russian State Standard GOST 8486, the output of timber with similar strength values is much greater when graded by the aggregate knot volume parameter.

$100 \%$ of spruce timber has strength of no less than $30 \mathrm{MPa}$, when graded by the aggregate knot volume parameter, whereas $83 \%$ of pinewood timber has strength of no less than $24 \mathrm{MPa}$. When graded by Russian State Standard GOST 8486, the output of grade 2 timber planks, with strength under bending

Byzov V.E., Melekhov V.I. Structural sawn timber: resource enhancement. Magazine of Civil Engineering. 2016. No. 5. Pp. 67-76. doi: 10.5862/MCE.65.5 
through loading on the edge of no less than $24 \mathrm{MPa}$, equals $63 \%$ for spruce timber and $40 \%$ for pinewood.

\section{Conclusions}

1. Theoretical and empirical data demonstrate that visual grading may ensure the predetermined characteristic strength of beams with required confidential probability.

2. When grading according to the substantiated standards of aggregate knot volume with account to the deflected mode of beams in load-bearing structures, the accuracy of beam strength assessment is higher than when timber grading is based on the current standard.

3. Distribution of strength properties of beams graded in accordance with the developed standards qualitatively outperforms the distribution of strength properties graded under GOST 8486. This allows us to use shaped timber elements with a small cross section produced from small logs in construction, use additional raw material resources, and contribute to solving the problems related to resource conservation.

4. Higher values of characteristic strength of timber allow compensating the decrease in loadbearing capacity resulting from the decreased cross section of load-bearing structure components due to the lack of saw log of the desired diameter.

5. The flat framing structure made from beams, which strength is evaluated pursuant to the developed standards, is characterized by increased structural stiffness and a double standard strength reserve.

6. If the developed requirements are included into the standards of timber grading, additional timber can be allocated for production of load-bearing engineering structures.

7. The technology of structural timber production technology will be simplified due to production of sawn timber for specific purposes.

\section{References}

1. Borovikov A.M. Kachestvo pilomaterialov [Quality of sawn timber]. Moscow: Lesnaya promyshlennost, 1990. 256 p. (rus)

2. Savkov Ye.I. Prochnost pilomaterialov [Strength of sawn timber]. Moscow: Goslesbumizdat, 1962. 88 p.(rus)

3. Miller D.G. Selective efficiencies of nordestructive strength test. Forest Products Journal. 1962. Vol.5. No.8: Pp. 87-92.

4. Dean M.A., Kaiserlik Y.N. Nondestructive screening of hardvood specialty blanks. Forest Products Journal. 1984. Vol. 34. No. 3. Pp. 51-56.

5. VVT Technical Research Centre of Finland Ltd. Grading of timber for engineered wood products (Gradewood). Final report. 2006. 34 p.

6. Ugolev B.N. Wood as natural smart material. Wood Science and Technology. 2014. Vol. 48. No. 3. Pp. 553568.

7. Ylinen A. Über den mechanische Schaftformtheorie der Bäume. Techn. Hochschule in Finnland, Wiss. Forschungen. Helsinki, 1952. 51 p.

8. Ashkenazi Ye.K. Anizotropiya drevesiny i drevesnykh materialov [Anisotropy of timber and timber-based materials]. Moskow: Lesnaya promyshlennost, 1978. 224 p. (rus)

9. Melekhov V.I., Byzov V.Ye. Rasshireniye resursov pilomaterialov dlya nesushchikh stroitelnykh konstruktsiy [The expansion of resources for load-building structures]. lzvestiya Sankt-Peterburgskoy lesotekhnicheskoy akademii. 2015. No. 213. Pp. 204-211. (rus)

10. Miller D.G. Effect of Tolerance on Selection Efficiency of Wood. Forest Products Journal. 1964. No. 4(14). Pp. 179-183.

11. Karelskiy A.V., Zhuravleva T.P., Labudin B.V. Ispytaniye na izgib derevyannykh sostavnykh balok, soyedinennykh metallicheskimi zubchatymi plastinami, razrushayushchey nagruzkoy [Load-to-failure test of wood composite beams connected by gang nail]. Magazine of Civil Engineering. 2015. No. 2(54). Pp. 125-127. (rus)

12. Neklyudova Ye.A., Semenov A.S., Melnikov B.Ye., Semenov S.G. Eksperimentalnyye issledovaniya $\mathrm{i}$ analiz

\section{Литература}

1. Боровиков А.М. Качество пиломатериалов. М.: Лесная промышленность, 1990. 254 с.

2. Савков Е.И. Прочность пиломатериалов. М.: Гослесбумиздат, 1962. 88c.

3. Miller D.G. Selective Efficiencies of Nordestructive Strength Test // Forest Products Journal. 1962. Vol. 5 № 8.Pp. 87-92.

4. Dean M.A., Kaiserlik Y.H. Nondestructive Screening of Hardvood Specialty. Blanks // Forest Products Journal. 1984. Vol. 34. № 3. Pp. 51-56.

5. VVT Technical Research Centre of Finland Ltd. Grading of timber for engineered wood products (Gradewood). Final report. 2006. 34 p.

6. Ugolev B.N. Wood as natural smart material // Wood science and technology. 2014. Vol. 48. № 3. Pp. 553568 .

7. Ylinen A. Über den mechanische Schaftformtheorie der Bäume. Techn. Hochschule in Finnland, Wiss. Forschungen. Helsinki, 1952. 51 p.

8. Ашкенази Е.К. Анизотропия древесины и древесных материалов. М.: Лесная промышленность, 1978. 224 c.

9. Мелехов В.И., Бызов В.Е. Расширение ресурсов пиломатериалов для несущих строительных конструкций // Известия Санкт-Петербургской лесотехнической академии. 2015. № 213. С. 204-211.

10. Miller D.G. Effect of Tolerance on Selection Efficiency of Wood // Forest Products Journal. 1964. № 4(14). Pp. 179-183.

11. Карельский А.В., Журавлёва Т.П., Лабудин Б.В Испытание на изгиб деревянных составных балок, соединённых металлическими зубчатыми пластинами, разрушающей нагрузкой // Инженерностроительный журнал. 2015. № 2(54). С. 77-127.

12. Неклюдова Е.А., Семёнов А.С., Мельников Б.Е., Семёнов С.Г. Экспериментальные исследования и анализ методом конечных элементов прочностных и упругих характеристик композитного материала из стеклопластика // Инженерно-строительный журнал. 2014. № 3(47). C. 25-39.

Бызов В.Е., Мелехов В.И. Увеличение ресурсов конструкционных пиломатериалов для строительных конструкций // Инженерно-строительный журнал. 2016. № 5(65). С. 67-76. 
metodom konechnykh elementov prochnostnykh i uprugikh kharakteristik kompozitnogo materiala iz stekloplastika [Experimental research and finite element analysis of elastic and strength properties of fibreglass composite material]. Magazine of Civil Engineering. 2014. No. 3(47). Pp. 25-39. (rus)

13. Chubinskii A.N. Phisical Nondestructive Methods for linkthe Testing and Evalustion of the Structure of Wood Based Materials [Phisical Nondestructive Metods for linkhe Testing and Evalustion of the Structure of Wood Based Materials]. Russian Journal of Nondestructive Testing. 2014. No. 11. Pp. 693-700. (rus)

14. Wei Q., Leblon B., La Rocque A. On the use of X-ray computed tomography for determining wood properties: a review. Canadian Journal of Forest Research. 2011. No. 41. Pp. 2120-2140.

15. Tambi A.A. Prognozirovaniye prochnostnykh kharakteristik pilomaterialov [Prediction of the strength characteristics of lumber]. Materialy nauchnoprakticheskoy konferentsii (Sovremennyye problemy pererabotki drevesiny) [Materials of scientific-practical conference (Modern problems of wood processing)] Saint-Petersburg.: Izd-vo Politekhn. un-ta, 2013. Pp. 4045. (rus)

16. Melekhov V.I., Byzov V.Ye. Vliyaniye serdtsevinnykh vklyucheniy na prochnostnyye kharakteristiki konstruktsionnykh pilomaterialov [Influence of pith inclusions on strength properties of structural timber] Construction materials. 2010. No. 12. Pp. 80-81. (rus)

17. Kendall M.G. Rank correlation methods. 4th ed. Griffin London, 1975.

18. Piao C., Groom L. Residual strength and stiffness of lumber from decommioned chromate copper arsenatetreated southern pine utility poles. Forest Products Journal. 2010. Vol. 60. No. 2. Pp. 166-172.

19. Horvath B., Peszen I., Perolta P., Horvath L., Kasal B., Li $\mathrm{L}$. Elastic modulus determination of transgenic aspen using a dynamic mechanical analyzer in static bending mode. Forest Products Journal. 2010. Vol.60. No. 3 Pp. 296-300

20. Chauzov K.V., Koltunova T.V, Tambi A.A. K voprosu o sortoobrazovanii pilomaterialov na osnove trebovaniy, predyavlyayemykh $k$ konechnoy produktsii [To the question of sortabletable lumber on the basis of the requirements for the final product]. Sbornik nauchnykh trudov III Mezhdunarozhnoy nauchno-tekhnicheskoy konferentsii (Aktualnyye problemy i perspektivy razvitiya lesopromyshlennogo kompleksa) [Collection of scientific proceedings of the 3 international scientific-technical conference (Actual problems and prospects of development of timber industrial complex)]. Kostroma: KGTU, 2015. Pp. 40-42. (rus)

21. Rykunin S.N., Vladimirova Ye.G. Sortirovaniye pilomaterialov na gruppy katchestva [Sawn timber grading on quality groups]. Lesnoy vestnik. 2012. No. 3 . Pp. 89-91. (rus)

22. Ogurtsov V.V. Printsipy opredeleniya dopuskov pri avtomaticheskoy sortirovke pilomaterialov po mekhanicheskim svoystvam [Principles of determination of tolerance for automatic grading of sawn timber according to its mechanical properties]. Forestry magazine. 1980. No. 1. Pp. 98-102.(rus)

Viktor Byzov,

+7(981)1220539; mapana@inbox.ru

Vladimir Melekhov,

88182216149; Iti@narfu.ru
13. Chubinskii A.N. Phisical Nondestructive Methods for linkthe Testing and Evalustion of the Structure of Wood Based Materials // Russian Journal of Nondestructive Testing. 2014. № 11. Pp. 693-700.

14. Wei Q., Leblon B., La Rocque A. On the use of X-ray computed tomography for determining wood properties: a review // Canadian Journal of Forest Research. 2011. No. 41. Pp. 2120-2140.

15. Тамби А.А. Прогнозирование прочностных характеристик пиломатериалов // Материалы научнопрактической конференции (Современные проблемы переработки древесины) СПб.: Изд-во Политехн. унта, 2013. C. $40-45$.

16. Мелехов В.И., Бызов В.Е. Влияние сердцевинных включений на прочностные характеристики конструкционных пиломатериалов // Строительные материалы. 2010. № 12. С. 80-81.

17. Kendall M.G. Rank correlation methods. 4th ed. London: Griffin, 1975.

18. Piao C., Groom L. Residual strength and stiffness of lumber from decommioned chromate copper arsenatetreated southern pine utility poles // Forest Products Journal. 2010. Vol. 60. № 2. Pp. 166-172.

19. Horvath B., Peszen I., Perolta P., Horvath L., Kasal B., Li L. Elastic modulus determination of transgenic aspen using a dynamic mechanical analyzer in static bending mode // Forest Products Journal. 2010. Vol.60. № 3. Pp. 296-300.

20. Чаузов К.В., Колтунова Т.В., Тамби А.А., Чубинский А.Н. К вопросу о сортообразовании пиломатериалов на основе требований, предъявляемых к конечной продукции // Сборник научных трудов III Междунарожной научно-технической конференции (Актуальные проблемы и перспективы развития лесопромышленного комплекса). Кострома: Изд-во КГТУ, 2015. С. 40-42.

21. Рыкунин С.Н., Владимирова Е.Г. Сортирование пиломатериалов на группы качества // Лесной вестник. 2012. № 3. С. 89-91.

22. Огурцов В.В. Принципы определения допусков при автоматической сортировке пиломатериалов по механическим свойствам // Лесной журнал. 1980. № 1. C. 98-102.

Виктор Евгеньевич Бызов, +7(981)1220539; эл. почma: mapana@inbox.ru

Владимир Иванович Мелехов, 88182216149; эл. почта: Iti@narfu.ru 